\title{
Eddy covariance VOC emission and deposition fluxes above grassland using PTR-TOF
}

\author{
T. M. Ruuskanen ${ }^{1, *}$, M. Müller ${ }^{1,2^{* *}}$, R. Schnitzhofer ${ }^{1,2}$, T. Karl ${ }^{1,3}$, M. Graus ${ }^{1, * * *}$, I. Bamberger ${ }^{1}$, L. Hörtnagl ${ }^{4}$, \\ F. Brilli ${ }^{2}$, G. Wohlfahrt ${ }^{4}$, and A. Hansel ${ }^{1}$ \\ ${ }^{1}$ Institute of Ion Physics and Applied Physics, University of Innsbruck, Innsbruck, Austria \\ ${ }^{2}$ Ionicon Analytik, Innsbruck, Austria \\ ${ }^{3}$ Atmospheric Chemistry Division, National Center for Atmospheric Research, Boulder, CO 80307, USA \\ ${ }^{4}$ Institute of Ecology, University of Innsbruck, Innsbruck, Austria \\ * current address: Division of atmospheric Sciences, Department of Physics, University of Helsinki, Helsinki, Finland \\ ** current address: UMR 5256, IRCELYON CNRS, Université Lyon 1, Lyon, France \\ **** current address: Chemical Sciences Division, NOAA Earth System Research Laboratory, Boulder, CO, USA
}

Received: 17 August 2010 - Published in Atmos. Chem. Phys. Discuss.: 2 September 2010

Revised: 13 December 2010 - Accepted: 21 December 2010 - Published: 20 January 2011

\begin{abstract}
Eddy covariance (EC) is the preferable technique for flux measurements since it is the only direct flux determination method. It requires a continuum of high time resolution measurements (e.g. 5-20 Hz). For volatile organic compounds (VOC) soft ionization via proton transfer reaction has proven to be a quantitative method for real time mass spectrometry; here we use a proton transfer reaction time of flight mass spectrometer (PTR-TOF) for $10 \mathrm{~Hz}$ EC measurements of full mass spectra up to $m / z 315$. The mass resolution of the PTR-TOF enabled the identification of chemical formulas and separation of oxygenated and hydrocarbon species exhibiting the same nominal mass. We determined 481 ion mass peaks from ambient air concentration above a managed, temperate mountain grassland in Neustift, Stubai Valley, Austria. During harvesting we found significant fluxes of 18 compounds distributed over 43 ions, including protonated parent compounds, as well as their isotopes and fragments and VOC- $\mathrm{H}^{+}-$water clusters. The dominant BVOC fluxes were methanol, acetaldehyde, ethanol, hexenal and other $\mathrm{C}_{6}$ leaf wound compounds, acetone, acetic acid, monoterpenes and sequiterpenes.
\end{abstract}

The smallest reliable fluxes we determined were less than $0.1 \mathrm{nmol} \mathrm{m}^{-2} \mathrm{~s}^{-1}$, as in the case of sesquiterpene emissions from freshly cut grass. Terpenoids, including mono- and sesquiterpenes, were also deposited to the grassland before and after the harvesting. During cutting, total VOC emission

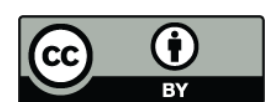

Correspondence to: A. Hansel (armin.hansel@uibk.ac.at) fluxes up to $200 \mathrm{nmolC} \mathrm{m}^{-2} \mathrm{~s}^{-1}$ were measured. Methanol emissions accounted for half of the emissions of oxygenated VOCs and a third of the carbon of all measured VOC emissions during harvesting.

\section{Introduction}

Traditional flux measurement techniques of volatile organic compounds (VOCs) using proton-transfer-reaction - massspectrometry (PTR-MS) enable either eddy covariance (EC) measurement of one compound or disjunct eddy covariance (DEC) of several selected volatile organic compounds (e.g. Karl et al., 2001a). Conventional PTR-MS uses a quadrupole mass filter which allows measuring one mass at a time with a mass separation capability of one atomic mass unit. The newly developed PTR - time-of-flight (PTR-TOF) (Graus et al., 2010; Jordan et al., 2010) can measure $10 \mathrm{~Hz}$ time series of full mass spectra with a mass accuracy sufficient to determine chemical formulas (i.e. separate oxygen containing VOCs from pure hydrocarbons). Data processing methods of continuous high-time and high-mass resolution PTR-TOF data has previously been described by Graus et al. (2010). It was demonstrated that a mass resolution of $4400 \mathrm{~m} / \Delta \mathrm{m}$ and a mass accuracy of $2.5 \mathrm{ppm}$ can be achieved if internal calibrations of the temperature dependent mass scale are continuously performed. Unlike in the PTR-MS where transmission decreases drastically after $100 \mathrm{~m} / \mathrm{z}$, the PTR-TOF sensitivity increases towards heavier compounds providing enhanced detection capacity of semi-volatile organic compounds. The

Published by Copernicus Publications on behalf of the European Geosciences Union. 
$10 \mathrm{~Hz}$ measurement of full mass spectra and gain in sensitivity at high masses is in particular important when determining simultaneous emissions of heavier compounds (for example protonated sesquiterpenes at $205.1945 \mathrm{~m} / \mathrm{z}$ ) and the deposition of oxidation products of emitted VOCs. The features of the PTR-TOF enable simultaneous measurement of EC fluxes of all protonated VOCs, no longer constraining the flux measurements to a preselected set of a limited number of compounds. Müller et al. (2010) described how the $10 \mathrm{~Hz}$ TOF dataset can be binned to infer compound specific count rates for spectra that contain up to 150000 time-offlight bins. We show how to widen the VOC flux measurements from a hand full of species measurable by the PTR-MS combined with DEC to the measurement of simultaneous EC fluxes of all species detectable by the PTR-method with the PTR-TOF. Determining simultaneous EC fluxes opens up a new possibility to screen fluxes for a wide range of organic compounds and allows determining their fate in the atmosphere (e.g. deposition fluxes) ultimately improving the understanding of VOC biosphere-atmosphere-interactions. Due to the rapid mass scanning ability of the PTR-TOF, the sum of emissions of all detectable VOCs can be measured to decrease the uncertainty in the amount of carbon released as VOCs (Chapin et al., 2006), to investigate the role of VOCs in the missing reactivity observed in OH-reactivity measurements (e.g. Sinha et al., 2010), and to explore the argument that the current emission inventories may miss up to half of the reactive carbon as a VOC flux entering the atmosphere (Goldstein and Galbally, 2007; di Carlo et al., 2004).

Current estimates of the annual production rate of secondary organic aerosols (SOA) lie between 12 and $200 \mathrm{Tg} /$ year (Kanakidou et al., 2005; Hallquist et al., 2009), mainly due to gaps of knowledge in aerosol formation processes and to the uncertainty of emissions of biogenic and anthropogenic SOA precursors. SOA formation has been related to growth from BVOCs that are oxidized in the atmosphere (e.g. Claeys et al., 2004; Tunved et al., 2006; Laaksonen et al., 2008). Mono- and sesquiterpenes have been identified to take part in SOA formation; due to large uncertainties in the primary emissions of VOCs more SOA precursors are expected to be found (Kanakidou et al., 2005). Recent findings suggest that organic compounds can take part in the nucleation itself (Metzger et al., 2010) and that the composition of the available BVOCs is important, while Kiendler-Scharr et al. (2009) found that in certain conditions isoprene can also reduce organic aerosol formation. Therefore it is no surprise, that SOA is currently poorly constrained in regional air quality models as well as in global climate models. The lack of understanding SOA formation also presents a significant uncertainty for radiative forcing calculations used to assess climate change (IPCC, 2007).

BVOC emissions depend on the plant species and are affected by plant development, acclimation and various stresses (e.g. Ninemets et al., 2010). In addition to the seasonal and annual variation in plant BVOC emissions, changes in land use and grown crop species may affect the atmospheric VOC composition. Ambitious expansion of the biofuel industry receives growing interest for offsetting carbon emissions. This could have consequences for air quality mitigation strategies if selected biofuel crops emit significant amounts of reactive VOCs that in return increase tropospheric ozone production. Lawn mowing activities have also been identified as a source of reactive VOCs (Karl et al., 2001b) in urban areas, where ozone production tends to be limited by the availability of VOCs.

In this paper, we revisit the question of reactive VOC emissions from harvesting and grass cutting activities using a PTR-TOF and simultaneously survey fluxes of all compounds detectable with the PTR-method. We expand the analysis procedures described by Müller et al. (2010) and present PTR-TOF data processing methods for flux calculations of a wide range of compounds with different properties. In particular we evaluate basic quality control procedures necessary for finding correct lag-times in the PTR-TOF dataset to determine which ions $(\mathrm{m} / \mathrm{z})$ in the mass spectra are emitted or deposited. We list factors that must be taken into account when identifying emitted and deposited compounds using PTR-TOF measurements. We also discuss the reliability of the obtained fluxes and the confidence of absolute flux values using results from $10 \mathrm{~Hz}$ VOC measurements over grassland during periods characterized by growing, drying of cut grass and grass after harvesting.

\section{Methods}

\subsection{Field site}

VOC fluxes were measured at a field site above a temperate mountain grassland, in the Stubai valley, Austria, close to the village of Neustift $\left(47^{\circ} 07^{\prime} \mathrm{N}, 11^{\circ} 19^{\prime} \mathrm{E}\right)$ at $970 \mathrm{~m}$ a.s.l. The measurement location is in the middle of the flat valley bottom and the flux footprint consists mainly of two patches with similar vegetation that are intensively managed by two different farmers. Graminoids make up on average $20-40 \%$ of the total above-ground biomass, the rest being forbs (Wohlfahrt et al., 2010). A detailed description of the field site, including a description of vegetation, soil and climate, is given by Wohlfahrt et al. (2008). Bamberger et al. (2010) have described diurnal patterns of methanol, acetaldehyde, and leaf wound compound fluxes during harvesting at the field site from disjunct eddy covariance measurements of 15 masses using a PTR-MS.

Here we present an 8 day case study of fluxes for three sunny periods from August 2009: intact fully grown grassland with a green area index (GAI) of $6.5 \mathrm{~m}^{2} \mathrm{~m}^{-2}$ (intact grass, 1-2 August), cut and drying grass (cut grass; 5-6 August) and the field after the grass had been removed, with a GAI of $1.7 \mathrm{~m}^{2} \mathrm{~m}^{-2}$ (after harvesting; 7-8 August). During the period of intact grass 1-2 August, daytime temperature 
maximum was $29^{\circ} \mathrm{C}$ and nighttime minimum $8^{\circ} \mathrm{C}$. The 3 August was a cool, cloudy and rainy day, with daytime maxima of $17^{\circ} \mathrm{C}$ and $28 \mathrm{~mm}$ of rain. The edges of the field patch were cut on the evening of the 4 August and the patch itself was cut at 09:00 a.m. (all times in Central European Time) and left to dry on 5 August. The cut grass was turned on 5 August and in the morning on 6 August; it was removed between 02:30 and 05:00 p.m. on 6 August. After the grass cutting the days were sunny and the temperatures varied between $10^{\circ} \mathrm{C}$ (nighttime) and $25^{\circ} \mathrm{C}$ (daytime).

\subsection{Instrumentation}

The three wind components and the speed of sounds were measured using a three-dimensional sonic anemometer (R3IA, Gill Instruments, Lymington, UK) at $20 \mathrm{~Hz}$ acquisition frequency. The VOC inlet was mounted $2.5 \mathrm{~m}$ a.g., and 0.1 below and laterally $0.1 \mathrm{~m}$ from the center of the 3-D sonic anemometer. Sample air was drawn through a temperature stabilized $\left(35^{\circ} \mathrm{C}\right), 12 \mathrm{~m}$ long $1 / 4^{\prime \prime}$ Teflon ${ }^{\circledR}$ tube (ID $3.9 \mathrm{~mm}$ ) to the PTR-TOF with a constant flow of 9 standard liter per minute (SLPM). We heated the PTR-TOF drift tube to $50{ }^{\circ} \mathrm{C}$ and operated at $600 \mathrm{~V}$ drift voltage and 2.3 mbar drift tube pressure, corresponding to an $\mathrm{E} / \mathrm{N}$ ratio of about $130 \mathrm{Td}(\mathrm{E}$ being the electric field strength and $\mathrm{N}$ the gas number density; $1 \mathrm{Td}=10^{-17} \mathrm{~V} \mathrm{~cm}^{2}$ ). We measured instrumental background (zero calibration) 2-4 times per day (each time for $25 \mathrm{~min}$ ) at ambient humidity levels using VOC-free air from a continuously flushed, home-built catalytic converter at $350^{\circ} \mathrm{C}$. Sensitivity calibrations were performed by dynamic dilution of VOCs using $10 \mathrm{mlpm}$ (ml per minute), $5 \mathrm{mlpm}$ and $0 \mathrm{mlpm}$ of a multi-component gas standard (Apel Riemer Environmental Inc., USA) and $200 \mathrm{mlpm}$ VOC-free air used in background measurements on 31 July and 8 August. The calibration gas contained acetone, acetonitrile, acrolein, benzene, 2-butanone, ethanol, formaldehyde, hexanone, isoprene, methanol, monoterpenes ( $\alpha$-pinene), nonanone, octanone, toluene, $o$ - and $p$-xylene in the ranges of $50 \mathrm{ppbv}$, $25 \mathrm{ppbv}$ and $0 \mathrm{ppbv}$, respectively. The instrument performance was stable, as an example, methanol sensitivity was $33 \mathrm{cps} / \mathrm{ppbv}$ and acetone $70 \mathrm{cps} / \mathrm{ppbv}$ and the sensitivities varied only $2.2 \%$ between the calibrations. The oxygen containing compounds (acetone, acrolein, hexanone, octanone and nonanone) had a higher average normalized sensitivity of $26.6 \mathrm{ncps} / \mathrm{ppbv}$ (between 22.5 and $31.1 \mathrm{ncps} / \mathrm{ppbv}$ ) than the pure hydrocarbons (isoprene, toluene and xylene) that had an average normalized sensitivity of $15.0 \mathrm{ncps} / \mathrm{ppbv}$ (between 12.6 and $18.1 \mathrm{ncps} / \mathrm{ppbv})$. For the compounds that were not calibrated, we used the average normalized sensitivities for oxygen containing compounds and for pure hydrocarbons, respectively. The volume mixing ratios (in moist air, denoted ppbv), obtained using corresponding sensitivities, were converted to concentrations $\mathrm{nmol} \mathrm{m}^{-3}$ for the flux calculations using the ideal gas law and measured air temperature and pressure. The time-of-flight path length is sensitive to temperature variation and therefore mass scale calibration was done continuously by adding dichlorobenzene (protonated $\mathrm{m} / \mathrm{z}=146.9763$ ) and trichlorobenzene (protonated $m / z=180.9373$ ) to the PTR-TOF inlet. A thorough description and characterization of the PTR-TOF instrument is given by Graus et al. (2010). Müller et al. (2010) describe the data acquisition and processing methods used for flux measurements in detail which will be described only shortly below.

The PTR-TOF determines the arrival times of all ions with a $0.2 \mathrm{~ns}$ time resolution resulting in 150000 "bins" per spectrum with a Multi Channel Plate and a Time to Digital Converter (TDC). By storing 3333 co-added extractions per spectra we measured a $10 \mathrm{~Hz}$ time series of full PTR-TOF spectra. The data was acquired in 6 min segments (hdf5 file format (http://www.hdfgroup.org/)) using the TOF-DAQ v1.72 software (Tofwerk AG, Switzerland). Each of the 6 min PTRTOF spectra was mass scale corrected using Matlab (Mathworks, USA) based functions by M. Müller that have been described by Müller et al. (2010). We obtained one mass scale spectrum each $0.1 \mathrm{~s}$ between $\mathrm{m} / \mathrm{z} 20$ and $\mathrm{m} / \mathrm{z} 315$. The ion counts were inferred from peak fitting of the six minute sum spectra. The measured mass resolving power $(\mathrm{m} / \Delta m)$ and mass accuracy - determined from the calibration data were 4800 and better than 10 ppm, respectively. The mass accuracy was sufficient to determine chemical formulas; for example to separate pure hydrocarbons from oxygen containing VOCs.

\subsection{VOC flux calculations and quality assurance}

We calculated eddy covariance fluxes for 481 mass peaks from the $10 \mathrm{~Hz}$ PTR-TOF and the $20 \mathrm{~Hz}$ sonic anemometer data, which were collected to two separate computers, using a Matlab-routine based on the method described by Karl et al. (2002). We re-sampled the $20 \mathrm{~Hz}$ wind data to match the $10 \mathrm{~Hz}$ VOC data and applied a coordinate rotation of the wind data according to the planar fit method (Wilczak et al., 2001). Any time shift between the vertical wind velocity and the VOC concentrations, which were smoothed and de-trended to this end, due to the residence time of the air in the tube and differences in computer clocks was determined by the maximum covariance method in a $\pm 2 \mathrm{~s}$ time window and removed (note that negative time shifts may occur if the clock of the sonic anemometer computer lags behind the PTRTOF computer more than the tube lag time). If a maximum (or minimum) was not found within a $\pm 2 \mathrm{~s}$ time window we used a lag-time of $2 \mathrm{~s}$ or - when available - chose the previously determined lag-time. High- and lowpass filtering of signals occurs due to a finite averaging interval (30 min), signal de-trending, damping and phase shift due to effects such as sampling through a tube, imperfect sensor time response, sensor separation, etc., leading to an underestimation of fluxes (Massman, 2000). Proper correction for these effects requires a detailed cospectral analysis of a larger 
data sample (e.g. Wohlfahrt et al., 2005) than available from the 8-day study period and thus we decided not to correct for high- and low-pass filtering effects. Changes in air density due to fluctuations of air temperature and/or humidity have only minor affects on the VOC concentrations measured with PTR technology, unlike in the case of analyzers that are not pressure or temperature controlled e.g. open path measure IR absorption at a given distance, and thus the so called WPL correction (Webb et al., 1980) was not applied.

With this routine we calculated half-hour mean flux values for all 481 ion mass peaks determined from a 6 min average spectrum using peak fitting routines described by Müller et al. (2010). As a first quality control criterion we searched for fluxes that were either higher than $0.05 \mathrm{nmol} \mathrm{m}^{-2} \mathrm{~s}^{-1}$ or lower than $-0.05 \mathrm{nmol} \mathrm{m}^{-2} \mathrm{~s}^{-1}$ for at least $5 \%$ of the entire sampling period. This filtering resulted in 107 remaining ion mass peaks that were visually inspected for their fluxes. Chemical formulas were assigned to the remaining mass peaks which are listed in Table 1.

We selected half hour periods that fulfilled the quality criteria for reliable flux measurements (turbulence, stationary test, footprint) based on Bamberger et al. (2010). The halfhour flux uncertainty was calculated for each compound using a visual inspection for rating: fluxes that exhibited a distinct and well defined maximum (or minimum) of the covariance were rated as class-A fluxes; fluxes with poorly defined maxima (or minima) (e.g. broad peaks with no sharp maximum or minimum around the lag-time) were rated as class-B fluxes; other calculated flux values were considered as noise. We removed half-hour periods with clear anthropogenic influence indicated by benzene and toluene volume mixing ratios above 2 ppbv (in total $2.5 \mathrm{~h}$ ).

The flux uncertainty was determined from the noise of the covariance function in the manner proposed by Wienhold et al. (1994) and adapted by Spirig et al. (2005). The idea is to determine the general noise of the covariance by calculating the standard deviation of the covariance for time shifts between vertical wind velocity and concentration that are well beyond the integral time scale (calculated lag-time). Spirig et al. (2005) determined the noise of two $20 \mathrm{~s}$ lag windows; here we opened the noise window to $40 \mathrm{~s}$. Our calculated lag was around $0 \mathrm{~s}$ and we calculated the noise between lag-time ranges of $-190 \mathrm{~s}$ to $-150 \mathrm{~s}$ and $150 \mathrm{~s}$ to $190 \mathrm{~s}$ and multiplied it by 1.96 to get a $95 \%$ confidence interval for each flux measurement (Rinne et al., 2007).

\section{Results and discussion}

\subsection{Influence of water flux on VOC fluxes}

When determining the compounds that are emitted or deposited, it is important to take into account the possibility that the protonated mass peak flux is induced by the water flux and not by the flux of the protonated compound.
Changes in relative humidity of the sample air can affect the primary ion and water cluster distribution in the drift tube, especially under conditions of low to moderate collision energies in the drift tube. The simultaneous flux of water can influence fluxes observed for VOCs with humidity influenced detection. The fluxes of compounds that have a proton affinity high enough to enable a direct proton transfer from water clusters (mainly $\mathrm{H}_{2} \mathrm{OH}_{3} \mathrm{O}^{+}$and $\left(\mathrm{H}_{2} \mathrm{O}\right)_{2} \mathrm{H}_{3} \mathrm{O}^{+}$), in addition to the proton transfer from the primary ion $\left(\mathrm{H}_{3} \mathrm{O}^{+}\right)$, are influenced very little if at all. However, the flux of water will have a contribution if the compound is protonated by ligand switching: a flux artifact can result when the compound forms a ligand with the water cluster (that has a real flux), breaks down in the drift tube and is detected as a protonated compound. In addition, the compound - water-cluster flux is a combination of the flux of the compound and water. In the following section we will describe how to identify and take into account humidity influences on VOC fluxes.

\subsection{Identification of emitted and deposited compounds}

The PTR-TOF was used to detect emitted and deposited compounds and to identify their chemical formula, after the PTRTOF flux dataset was interpreted in detail and observation of one compound at several ions was taken into account. From the visual inspection we found 37 out of the 107 ion mass peaks that had a well defined covariance (referred to class-A fluxes), 12 ion mass peaks had only a poorly defined covariance (referred to class-B fluxes), and the rest (58) of the ion mass peak covariance functions did not show a local maximum or minimum and were associated with random covariance (noise). Class-B fluxes were typically observed for ion mass peaks with low signal intensities e.g. for isotopes of prototaned compounds and for compounds that had been ionized by charge transfer or had humidity dependent ion mass peak signals. Humidity dependent class-B fluxes were observed for several ions including protonated di- and trichlorobenzene that were added to the inlet by diffusion through a capillary for accurate and continuous mass scale calibration. Fluxes due to ionization by charge transfer of ions produced in the instrument (such as $\mathrm{O}_{2}^{+}, \mathrm{NO}^{+}, \mathrm{N}_{2} \mathrm{H}^{+}$, $\mathrm{CO}_{2} \mathrm{H}^{+}$) and humidity dependency were considered as measurement artifacts. Here we define a physically meaningful flux: (1) the flux was not a measurement artifact (2) the ion mass peak did not correspond to an isotope or VOC - water cluster or a fragment of a protonated compound exhibiting a flux. We consider that ion mass peaks with a physically meaningful flux corresponded to a compound that was truly emitted from or deposited to the grassland. We also excluded cases where the ion abundance was strongly humidity dependent, because in these cases the flux is masked by the large (Hammerle et al., 2008) latent heat flux. Large changes in latent heat fluxes during the drying of grass resulted in detectable changes of water cluster containing ions related to specific VOCs (e.g. methanol water-clusters). In the case of 
Table 1. Volatile organic compounds with emission or deposition flux above the grassland before, during or after harvesting, exact measured $\mathrm{m} / \mathrm{z}$ of well defined class-A fluxes (bold) or only less reliable class-B fluxes, exact mass of parent ion mass peak, isotopes, VOC-water clusters and fragments of the protonated parent compound.

\begin{tabular}{|c|c|c|c|c|}
\hline \multirow{2}{*}{$\begin{array}{l}\text { Molecular } \\
\text { formula }\end{array}$} & \multicolumn{4}{|c|}{ Likely compound } \\
\hline & Parent ion & Isotope & Water cluster & Fragment \\
\hline $\mathrm{CH}_{3} \mathrm{OH}-\mathrm{H}^{+}$ & $\begin{array}{l}\text { Methanol } \\
\text { 33.0336 }\end{array}$ & $\begin{array}{l}\mathbf{3 4 . 0 3 7 6} \\
35.0383\end{array}$ & 51.0445 & \\
\hline $\mathrm{C}_{2} \mathrm{H}_{3} \mathrm{OH}-\mathrm{H}^{+}$ & $\begin{array}{l}\text { Acetaldehy } \\
\mathbf{4 5 . 0 3 4 0}\end{array}$ & 46.0375 & & \\
\hline $\mathrm{C}_{2} \mathrm{H}_{5} \mathrm{OH}-\mathrm{H}^{+}$ & $\begin{array}{l}\text { Ethanol } \\
\mathbf{4 7 . 0 4 9 3}\end{array}$ & & & \\
\hline $\mathrm{C}_{6} \mathrm{H}_{8}-\mathrm{H}^{+}$ & $\begin{array}{l}\text { e.g. fragme } \\
81.0705\end{array}$ & $\begin{array}{l}\text { to } \mathrm{C}_{6} \text {-con } \\
\mathbf{8 2 . 0 7 3 8}\end{array}$ & ounds (e.g. her & Inal, hexenols) and terpenoids \\
\hline $\mathrm{C}_{6} \mathrm{H}_{10} \mathrm{O}-\mathrm{H}^{+}$ & $\begin{array}{l}\text { Green leaf } \\
\mathbf{9 9 . 0 8 1 1}\end{array}$ & $\begin{array}{l}\text { olatiles (e.g } \\
\mathbf{1 0 0 . 0 7 8 0}\end{array}$ & hexenals) & $\begin{array}{l}43.0183 \\
\mathbf{5 7 . 0 3 4 0}\end{array}$ \\
\hline $\mathrm{C}_{2} \mathrm{H}_{4} \mathrm{O}_{2}-\mathrm{H}^{+}$ & $\begin{array}{l}\text { Acetic acid } \\
\mathbf{6 1 . 0 2 9 1}\end{array}$ & & & 43.0183 \\
\hline $\mathrm{C}_{6} \mathrm{H}_{10}-\mathrm{H}^{+}$ & $\begin{array}{l}\text { e.g. fragme } \\
\mathbf{8 3 . 0 8 6 1}\end{array}$ & t of $\mathrm{C}_{6}$-con & ounds (e.g. her & hal, hexenols) \\
\hline $\mathrm{C}_{5} \mathrm{H}_{4} \mathrm{O}_{2}-\mathrm{H}^{+}$ & $\begin{array}{l}\text { e.g. furfura } \\
\mathbf{9 7 . 0 2 8 7}\end{array}$ & 62.0334 & & \\
\hline $\mathrm{C}_{3} \mathrm{H}_{6} \mathrm{O}-\mathrm{H}^{+}$ & $\begin{array}{l}\text { Acetone (a } \\
\mathbf{5 9 . 0 4 9 6}\end{array}$ & $\begin{array}{l}\text { d propanol) } \\
60.0530\end{array}$ & 77.0595 & \\
\hline $\mathrm{C}_{5} \mathrm{H}_{8}-\mathrm{H}^{+}$ & $\begin{array}{l}\text { Fragment } \mathrm{c} \\
\mathbf{6 9 . 0 7 0 5}\end{array}$ & $\begin{array}{l}\text { methylbuta } \\
\mathbf{7 0 . 0 7 4 3}\end{array}$ & als or pentenol & (and isoprene) \\
\hline $\mathrm{C}_{4} \mathrm{H}_{8} \mathrm{O}-\mathrm{H}^{+}$ & $\begin{array}{l}\text { e.g. butano } \\
\mathbf{7 3 . 0 6 5 3}\end{array}$ & $\begin{array}{l}\text {, butanal } \\
74.0655\end{array}$ & & \\
\hline $\mathrm{C}_{4} \mathrm{H}_{6} \mathrm{O}-\mathrm{H}^{+}$ & $\begin{array}{l}\text { Methyl-vin } \\
\mathbf{7 1 . 0 4 9 7}\end{array}$ & $\begin{array}{l}\text { l-ketone (an } \\
72.0534\end{array}$ & methacrolein) & \\
\hline $\mathrm{C}_{5} \mathrm{H}_{8} \mathrm{O}-\mathrm{H}^{+}$ & $\begin{array}{l}\text { e.g. pentan } \\
\mathbf{8 5 . 0 6 5 3}\end{array}$ & & & \\
\hline $\mathrm{C}_{5} \mathrm{H}_{10} \mathrm{O}-\mathrm{H}^{+}$ & $\begin{array}{l}\text { e.g. methyl } \\
\mathbf{8 7 . 0 8 1 0}\end{array}$ & utanals, pen & enols & 43.01833 \\
\hline $\mathrm{C}_{10} \mathrm{H}_{16}-\mathrm{H}^{+}$ & $\begin{array}{l}\text { Monoterpe } \\
\mathbf{1 3 7 . 1 3 3 0}\end{array}$ & $\begin{array}{l}\text { es (and sesq } \\
\mathbf{1 3 8 . 1 3 6 5}\end{array}$ & iterpene fragm & $\begin{array}{l}\text { 95.0862 } \\
\text { 81.0705, also see } \mathrm{C}_{6} \mathrm{H}_{8}-\mathrm{H}^{+}\end{array}$ \\
\hline $\mathrm{C}_{10} \mathrm{OH}_{16}-\mathrm{H}^{+}$ & $\begin{array}{l}\text { Terpenoid } \\
\mathbf{1 5 3 . 1 2 7 8}\end{array}$ & g. camphor & & \\
\hline $\mathrm{C}_{15} \mathrm{H}_{24}-\mathrm{H}^{+}$ & $\begin{array}{l}\text { Sesquiterp } \\
\mathbf{2 0 5 . 1 9 4 5}\end{array}$ & & & \\
\hline
\end{tabular}


isobaric ions (i.e. multiple peaks at one nominal mass), we discarded small mass peaks sitting on the shoulder of large mass peaks in the continuous mass spectrum, if the large mass peak exhibited a significant flux (Müller et al., 2010).

Based on the previous criteria we determined that $17 \mathrm{com}$ pounds that were either deposited to or emitted from the grassland were responsible for fluxes of 43 ions (Table 1). In addition to the ions listed in Table 1 fluxes were observed for ions that were associated with measurement artifacts due to ion chemistry related to VOC and water changes. The ions with an measurement artifact flux were: (1) oxygen (at $\mathrm{m} / \mathrm{z} 31.98899$ ), (2) neighboring mass peaks including a background impurity (at $m / z 33.01852$ ) affected by the neighboring methanol signal (described by Müller et al., 2010) as well as other neighboring mass peaks at 71.0860 and 83.0815 and 87.0810 and 97.0653 (see Table 1 for corresponding parent ions), (3) a nitrogen containing ion (at $\mathrm{m} / \mathrm{z}$ 35.0371) and (4) protonated di- and trichlorobenzene and their isotopes. We also observed class-B fluxes for a fragment of several compounds on $\mathrm{m} / \mathrm{z} 41.0385$ as well as on $\mathrm{m} / \mathrm{z}$ 63.027135, 63.0444, and 129.1284. The identification of chemical formulas of the given compound classes $\left(\mathrm{C}_{\mathrm{x}} \mathrm{H}_{\mathrm{y}} \mathrm{O}_{\mathrm{z}}^{+}\right)$based on the measured mass of molecular ions worked unambiguously within the limits determined by the instruments mass accuracy and precision similar to the performance shown in Graus et al. (2010). While this information identifies the atomic composition of VOCs, the PTR-TOF can not identify the chemical structure itself. We therefore assigned compound classes to these isobaric formulas. A single VOC may give several ions: (1) the protonated parent compound which is the most abundant ion in most cases; (2) an ion formed by charge transfer from $\mathrm{O}_{2}^{+}$and/or $\mathrm{NO}^{+}$, the sum of these primary ion impurities was always lower than $2 \%$ of the $\mathrm{H}_{3} \mathrm{O}^{+}$ ions, (3) protonated isotopes of the parent compound, (4) fragments of a protonated parent compound and (5) protonated VOC - water-clusters (VOC- $\left.\mathrm{H}^{+}-\left(\mathrm{H}_{2} \mathrm{O}\right)_{n}, n=1,2\right)$. Masses were sorted according to their likely protonated parent compound (see Table 1). When possible, fragments were assigned to their parent ion (protonated compound) based on known fragmentation patterns and flux ratios; e.g. over intact grass the fragment at $m / z 81.0705\left(\mathrm{C}_{6} \mathrm{H}_{8}-\mathrm{H}^{+}\right)$was clearly a monoterpene fragment and followed exactly the protonated monoterpene $\left(\mathrm{C}_{10} \mathrm{H}_{16}-\mathrm{H}^{+}, \mathrm{m} / z, 137.1330\right)$ flux behaviour (Table 2). However, when the grass was cut the $\mathrm{C}_{6} \mathrm{H}_{8}-\mathrm{H}^{+}$-fragment at $\mathrm{m} / z .81 .0705$ was the sum of protonated fragments from $\mathrm{C}_{6}$ leaf wound compounds (e.g. hexanal, hexenols) as well as monoterpenes. In cases when fragments could not be assigned to a single protonated parent compound, according to the emission intensities and patterns of the parent ions, they were lumped as a separate class of compounds (Tables 3-4).

In summary, correct identification of the emitted and deposited VOCs or their sum formulas requires, in addition to the high mass resolving power $(\mathrm{m} / \Delta m)$ and mass accuracy of the PTR-TOF, careful interpretation of the observed ions.

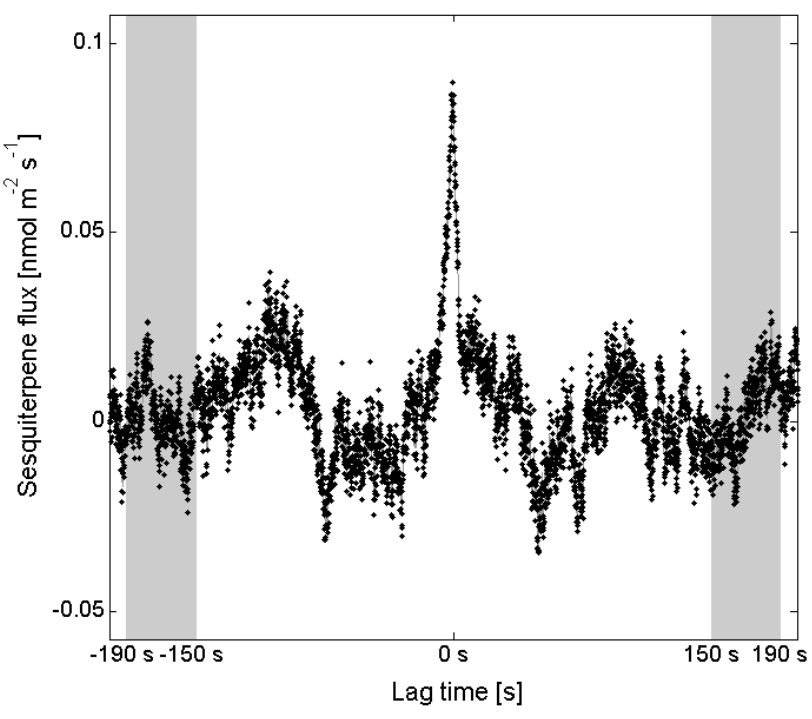

Fig. 1. Example of an eddy covariance flux of sesquiterpenes (at protonated compound mass peak $205.1945 \mathrm{~m} / \mathrm{z}$ ) visually rated as a class-A flux (5 August 2009 at 12:00-12:30). The flux was determined as the maximum covariance. The standard deviation of covariance in the shaded area was considered as the noise of the flux and used to calculate the flux confidence.

For example, methanol emission from drying grass gives rise to a positive flux of the protonated parent compound $\left(\mathrm{CH}_{3} \mathrm{OH}-\mathrm{H}^{+}, \mathrm{m} / \mathrm{z} 33.0336\right)$, the ${ }^{13} \mathrm{C},{ }^{17} \mathrm{O}$ or deuterium isotope $\left({ }^{13} \mathrm{CH}_{3} \mathrm{OH}-\mathrm{H}^{+}, \mathrm{CH}_{3} \mathrm{O}^{17} \mathrm{H}-\mathrm{H}^{+}\right.$and $\mathrm{CH}_{3} \mathrm{OH}-\mathrm{H}^{+}$where one $\mathrm{H}$ is a $\mathrm{D}, \mathrm{m} / \mathrm{z} 34.0376$ ), the ${ }^{18} \mathrm{O}$ or ${ }^{13} \mathrm{C}$ and $\mathrm{D}$ isotope $\left(\mathrm{CH}_{3} \mathrm{O}^{18} \mathrm{H}-\mathrm{H}^{+}, \mathrm{m} / z\right.$ 35.0383) and the protonated methanol water-cluster $\left(\mathrm{CH}_{3} \mathrm{OH}-\mathrm{H}-\mathrm{H}_{2} \mathrm{O}^{+}, \mathrm{m} / z\right.$ 51.045).

\subsection{Flux detection and confidence limits}

The smallest fluxes that we reliably calculated were less than $0.1 \mathrm{nmol} \mathrm{m}^{-2} \mathrm{~s}^{-1}$, as in the case of sesquiterpene emissions from freshly cut grass on 5 August from 11:00-11:30 (Fig. 1). The flux detection limit depends on vertical wind speed and the VOC signal, especially at low concentrations significant noise arises from the counting statistics of the detector (Lenschow and Kristensen, 1985). In addition, the flux at the calculated lag-time needs to exceed the general noise of the covariance function (Wienhold et al., 1994). The classA and class-B flux values always passed the $95 \%$-confidence interval (Fig. 2). The sign of the class-A fluxes calculated with the automated routine were consistent with the visually determined values, however this was not the case for some of the class-B. Due to the lack of a general detection limit, each half-hour flux value was inspected separately and only fluxes rated class-A were considered reliable and were used for further analysis. 
Table 2. VOC fluxes over intact grass during a sunny day $24 \mathrm{~h}$ between 11:00 CET on 1 August and 11:00 CET on 2 August in 2009 in Neustift, Stubai valley. Fluxes were calculated from the half-hour concentration and wind covariance and only class-A fluxes, with a well defined maximum or minimum in the covariance, were taken into account. The $95 \%$ flux confidence is calculated from the mean noise of class-A fluxes. The No. of 30-min fluxes shows how many class-A fluxes (emission or deposition) were observed.

\begin{tabular}{lllrrr}
\hline $\begin{array}{l}\text { Exact } \mathrm{m} / z \\
\text { measured }\end{array}$ & $\begin{array}{l}\text { Molecular } \\
\text { formula }\end{array}$ & Likely compound & $\begin{array}{r}\text { Mean flux } \\
(\mathrm{min} / \mathrm{max}) \\
\left(\mathrm{nmol} \mathrm{m}^{-2} \mathrm{~s}^{-1}\right)\end{array}$ & $\begin{array}{r}\text { Mean 95\% } \\
\text { confidence } \\
\left(\mathrm{nmol} \mathrm{m}^{-2} \mathrm{~s}^{-1}\right)\end{array}$ & $\begin{array}{r}30-\text { min } \\
\text { fluxes } \\
(\text { No. })\end{array}$ \\
\hline 33.0336 & $\mathrm{CH}_{3} \mathrm{OH}-\mathrm{H}^{+}$ & Methanol & $\begin{array}{r}5.89 \\
(1.14 / 9.31)\end{array}$ & 1.04 & 14 \\
205.1945 & $\mathrm{C}_{15} \mathrm{H}_{24}-\mathrm{H}^{+}$ & Sesquiterpenes & $\begin{array}{r}-0.03 \\
(-0.07 /-0.01)\end{array}$ & 0.01 & 6 \\
61.0291 & $\mathrm{C}_{2} \mathrm{H}_{4} \mathrm{O}_{2}-\mathrm{H}^{+}$ & Acetic acid & $\begin{array}{r}-0.18 \\
(-0.19 /-0.16)\end{array}$ & 0.10 & 2 \\
153.1278 & $\mathrm{C}_{10} \mathrm{OH}_{16}-\mathrm{H}^{+}$ & Terpenoid e.g. camphor & $\begin{array}{r}-0.19 \\
(-0.41 /-0.05)\end{array}$ & 0.01 & 11 \\
137.1330 & $\mathrm{C}_{10} \mathrm{H}_{16}-\mathrm{H}^{+}$ & $\begin{array}{l}\text { Monoterpenes (and } \\
\text { sesquiterpene fragment })\end{array}$ & $\begin{array}{r}-3.39 \\
(-8.21 /-0.21)\end{array}$ & 0.90 & 11 \\
\hline
\end{tabular}
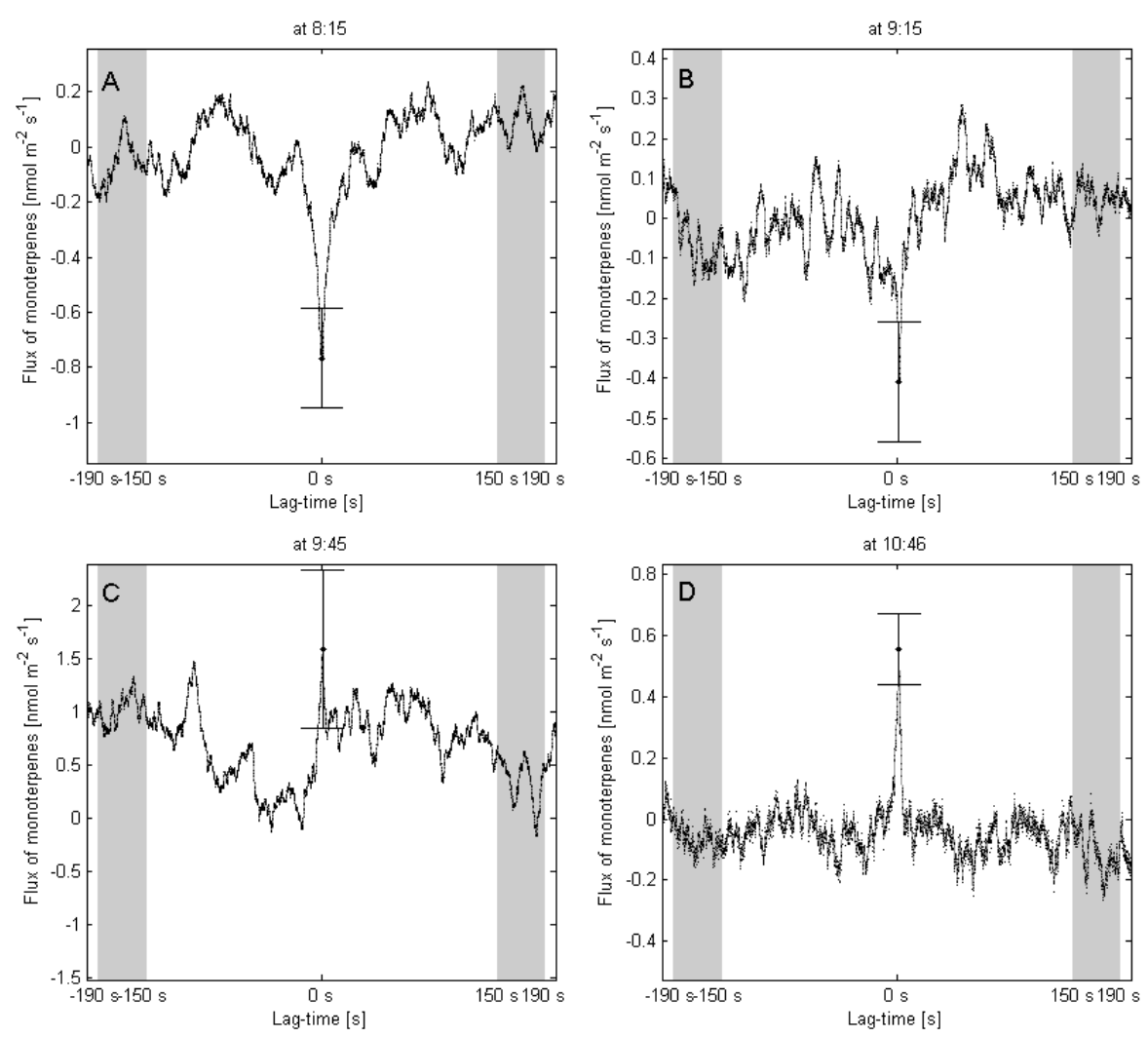

Fig. 2. Monoterpenes flux $(137.1330 \mathrm{~m} / \mathrm{z})$ during the morning of grass cutting on 5 August. The clear deposition to the intact grassland (A), changes during the grass cutting between 9 and 10:30 (B) and (C) into an emission (D) from some of the cut grass species that were left to dry on the field. The uncertainty of the flux is calculated by multiplying the standard deviation of the shaded areas with 1.96 to get the $95 \%$ confidence intervals indicated with bars. 
Table 3. VOC fluxes over drying cut grass during a sunny day for 24h between 11:00 CET on 5 August and 11:00 CET 6 August in 2009 in Neustift, Stubai valley. Fluxes were calculated from the half-hour concentration and wind covariance and only class-A fluxes, with a well defined maximum or minimum in the covariance, were taken into account. The $95 \%$ flux confidence is calculated from the mean noise of class-A fluxes. The $\mathrm{Nr}$ of 30-min fluxes shows how many class-A fluxes (emission or deposition) were observed, for mono- and sesquiterpenes we give No. of emission + deposition fluxes, separately.

\begin{tabular}{|c|c|c|c|c|c|}
\hline $\begin{array}{l}\text { Exact } m / z \\
\text { measured }\end{array}$ & $\begin{array}{l}\text { Molecular } \\
\text { formula }\end{array}$ & Likely compound & $\begin{array}{r}\text { Mean flux } \\
(\min / \max ) \\
\left(\mathrm{nmol} \mathrm{m} \mathrm{m}^{-2} \mathrm{~s}^{-1}\right)\end{array}$ & $\begin{array}{r}\text { Mean } 95 \% \\
\text { confidence } \\
\left(\mathrm{nmol} \mathrm{m}-2 \mathrm{~s}^{-1}\right)\end{array}$ & $\begin{array}{r}\text { 30-min } \\
\text { fluxes } \\
\text { (No.) }\end{array}$ \\
\hline 33.0336 & $\mathrm{CH}_{3} \mathrm{OH}-\mathrm{H}^{+}$ & Methanol & $\begin{array}{r}44.55 \\
(16.68 / 98.05)\end{array}$ & 6.65 & 15 \\
\hline 45.0340 & $\mathrm{C}_{2} \mathrm{H}_{3} \mathrm{OH}-\mathrm{H}^{+}$ & Acetaldehyde & $\begin{array}{r}6.66 \\
(0.83 / 10.68)\end{array}$ & 1.12 & 16 \\
\hline 47.0493 & $\mathrm{C}_{2} \mathrm{H}_{5} \mathrm{OH}-\mathrm{H}^{+}$ & Ethanol & $\begin{array}{r}4.80 \\
(2.42 / 8.21)\end{array}$ & 1.03 & 12 \\
\hline 81.0705 & $\mathrm{C}_{6} \mathrm{H}_{8}-\mathrm{H}^{+}$ & $\begin{array}{l}\text { e.g. fragment of } \mathrm{C}_{6^{-}} \\
\text {compounds (e.g. } \\
\text { hexanal, hexenols) } \\
\text { and terpenoids }\end{array}$ & $\begin{array}{r}2.31 \\
(0.43 / 7.55)\end{array}$ & 0.51 & 10 \\
\hline 99.0811 & $\mathrm{C}_{6} \mathrm{H}_{10} \mathrm{O}-\mathrm{H}^{+}$ & $\begin{array}{l}\text { green leaf volatiles } \\
\text { (e.g. hexenals) }\end{array}$ & $\begin{array}{r}2.19 \\
(0.48 / 7.92)\end{array}$ & 0.41 & 15 \\
\hline 61.0291 & $\mathrm{C}_{2} \mathrm{H}_{4} \mathrm{O}_{2}-\mathrm{H}^{+}$ & Acetic acid & $\begin{array}{r}1.21 \\
(0.53 / 1.96)\end{array}$ & 0.39 & 6 \\
\hline 83.0861 & $\mathrm{C}_{6} \mathrm{H}_{10}-\mathrm{H}^{+}$ & $\begin{array}{l}\text { e.g. fragment of } \mathrm{C}_{6^{-}} \\
\text {compounds (e.g. } \\
\text { hexanal, hexenols) }\end{array}$ & $\begin{array}{r}1.14 \\
(0.15 / 4.80)\end{array}$ & 0.23 & 14 \\
\hline 97.0287 & $\mathrm{C}_{5} \mathrm{H}_{4} \mathrm{O}_{2}-\mathrm{H}^{+}$ & e.g. furfural & $\begin{array}{r}1.12 \\
(0.05 / 4.49)\end{array}$ & 0.18 & 13 \\
\hline 59.0496 & $\mathrm{C}_{3} \mathrm{H}_{6} \mathrm{O}-\mathrm{H}^{+}$ & Acetone (and propanol) & $\begin{array}{r}1.10 \\
(0.54 / 2.17)\end{array}$ & 0.39 & 13 \\
\hline 69.0705 & $\mathrm{C}_{5} \mathrm{H}_{8}-\mathrm{H}^{+}$ & $\begin{array}{l}\text { Fragment of } \\
\text { methylbutanals } \\
\text { or pentenols } \\
\text { (and isoprene) }\end{array}$ & $\begin{array}{r}0.77 \\
(0.25 / 1.55)\end{array}$ & 0.20 & 8 \\
\hline 73.0653 & $\mathrm{C}_{4} \mathrm{H}_{8} \mathrm{O}-\mathrm{H}^{+}$ & e.g. butanone, butanal & $\begin{array}{r}0.56 \\
(0.44 / 0.68)\end{array}$ & 0.18 & 2 \\
\hline 71.0497 & $\mathrm{C}_{4} \mathrm{H}_{6} \mathrm{O}-\mathrm{H}^{+}$ & $\begin{array}{l}\text { Methyl-vinyl-ketone } \\
\text { and methacrolein }\end{array}$ & $\begin{array}{r}0.37 \\
(0.32 / 0.39)\end{array}$ & 0.07 & 5 \\
\hline 85.0653 & $\mathrm{C}_{5} \mathrm{H}_{8} \mathrm{O}-\mathrm{H}^{+}$ & e.g. pentanal & $\begin{array}{r}0.27 \\
(0.10 / 0.62)\end{array}$ & 0.06 & 13 \\
\hline 87.0810 & $\mathrm{C}_{5} \mathrm{H}_{10} \mathrm{O}-\mathrm{H}^{+}$ & $\begin{array}{l}\text { e.g. methylbutanals, } \\
\text { pentenols }\end{array}$ & $\begin{array}{r}0.27 \\
(0.07 / 0.71)\end{array}$ & 0.06 & 13 \\
\hline 137.1330 & $\mathrm{C}_{10} \mathrm{H}_{16}-\mathrm{H}^{+}$ & $\begin{array}{l}\text { Monoterpenes (and } \\
\text { sesquiterpene fragment) }\end{array}$ & $\begin{array}{r}0.13 \\
(-1.85 / 2.21)\end{array}$ & 0.03 & $5+4$ \\
\hline 153.1278 & $\mathrm{C}_{10} \mathrm{OH}_{16}-\mathrm{H}^{+}$ & Terpenoid e.g. camphor & $\begin{array}{r}0.10 \\
(0.09 / 0.11)\end{array}$ & 0.06 & 2 \\
\hline 205.1945 & $\mathrm{C}_{15} \mathrm{H}_{24}-\mathrm{H}^{+}$ & Sesquiterpenes & $\begin{array}{r}0.09 \\
(-0.01 / 0.23)\end{array}$ & 0.02 & $9+1$ \\
\hline
\end{tabular}

\subsection{Compounds emitted from and deposited to the grassland}

Unexpectedly, the dominant VOC fluxes over intact grass were, in addition to methanol emission fluxes, deposition fluxes of acetic acid and terpenoids (Table 2). The sign of acetic acid fluxes is known to depend on the ambient concentration (Kesselmeier and Staudt, 1999). As the ambient air concentration increases above the leaf-internal compensation point, the release from vegetation changes to deposition. However, the deposition of terpenoids comes as a surprise, since this group of compounds is typically associated 
Table 4. VOC fluxes after removal of cut grass during a sunny day between 08:00 CET on 7 August and 08:00 CET on 8 August in 2009 in Neustift, Stubai valley. Fluxes were calculated from the 30-min concentration and wind covariance and only class-A fluxes, with a well defined maximum or minimum in the covariance, were taken into account. The $95 \%$ flux confidence is calculated from the mean noise of class-A fluxes. The No. of 30-min fluxes shows how many class-A fluxes (emission or deposition) were observed, for and sesquiterpenes we give No. of emission + deposition fluxes, separately.

\begin{tabular}{|c|c|c|c|c|c|}
\hline $\begin{array}{l}\text { Exact } m / z \\
\text { measured }\end{array}$ & $\begin{array}{l}\text { Molecular } \\
\text { formula }\end{array}$ & Likely compound & $\begin{array}{r}\text { Mean flux } \\
(\min / \max ) \\
\left(\mathrm{nmol} \mathrm{m}^{-2} \mathrm{~s}^{-1}\right)\end{array}$ & $\begin{array}{r}\text { Mean } 95 \% \\
\text { confidence } \\
\left(\text { nmol m}{ }^{-2} \mathrm{~s}^{-1}\right)\end{array}$ & $\begin{array}{r}\text { 30-min } \\
\text { fluxes } \\
\text { (No.) }\end{array}$ \\
\hline 33.0336 & $\mathrm{CH}_{3} \mathrm{OH}-\mathrm{H}^{+}$ & Methanol & $\begin{array}{r}6.71 \\
(1.12 / 16.85)\end{array}$ & 1.27 & 26 \\
\hline 61.0291 & $\mathrm{C}_{2} \mathrm{H}_{4} \mathrm{O}_{2}-\mathrm{H}^{+}$ & Acetic acid & $\begin{array}{r}1.02 \\
(0.54 / 1.34)\end{array}$ & 0.32 & 7 \\
\hline 59.0496 & $\mathrm{C}_{3} \mathrm{H}_{6} \mathrm{O}-\mathrm{H}^{+}$ & Acetone (and propanol) & $\begin{array}{r}0.80 \\
(0.13 / 1.80)\end{array}$ & 0.71 & 5 \\
\hline 71.0497 & $\mathrm{C}_{4} \mathrm{H}_{6} \mathrm{O}-\mathrm{H}^{+}$ & $\begin{array}{l}\text { Methyl-vinyl-ketone } \\
\text { and methacrolein }\end{array}$ & $\begin{array}{r}0.24 \\
(0.14 / 0.32)\end{array}$ & 0.06 & 5 \\
\hline 83.0861 & $\mathrm{C}_{6} \mathrm{H}_{10}-\mathrm{H}^{+}$ & $\begin{array}{l}\text { e.g. fragment of } \\
\mathrm{C}_{6} \text {-compounds (e.g. } \\
\text { hexanal, hexenols) }\end{array}$ & $\begin{array}{r}0.10 \\
(0.07 / 0.12)\end{array}$ & 0.03 & 5 \\
\hline 99.0811 & $\mathrm{C}_{6} \mathrm{H}_{10} \mathrm{O}-\mathrm{H}^{+}$ & $\begin{array}{l}\text { Green leaf volatiles } \\
\text { (e.g. hexenals) }\end{array}$ & $\begin{array}{r}0.08 \\
(0.06 / 0.11)\end{array}$ & 0.02 & 5 \\
\hline 85.0653 & $\mathrm{C}_{5} \mathrm{H}_{8} \mathrm{O}-\mathrm{H}^{+}$ & e.g. pentanal & 0.07 & 0.03 & 1 \\
\hline 87.0810 & $\mathrm{C}_{5} \mathrm{H}_{10} \mathrm{O}-\mathrm{H}^{+}$ & $\begin{array}{l}\text { e.g. methylbutanals, } \\
\text { pentenols }\end{array}$ & $\begin{array}{r}0.08 \\
(0.07 / 0.09)\end{array}$ & 0.02 & 2 \\
\hline 205.1945 & $\mathrm{C}_{15} \mathrm{H}_{24}-\mathrm{H}^{+}$ & Sesquiterpenes & $\begin{array}{r}-0.01 \\
(-0.03 / 0.003)\end{array}$ & 0.01 & $1+7$ \\
\hline 153.1278 & $\mathrm{C}_{10} \mathrm{OH}_{16}-\mathrm{H}^{+}$ & Terpenoid e.g. camphor & $\begin{array}{r}-0.08 \\
(-0.11 /-0.05)\end{array}$ & 0.03 & 3 \\
\hline 81.0705 & $\mathrm{C}_{6} \mathrm{H}_{8}-\mathrm{H}^{+}$ & $\begin{array}{l}\text { e.g. fragment of } \mathrm{C}_{6^{-}} \\
\text {compounds and } \\
\text { terpenoids }\end{array}$ & $\begin{array}{r}-0.51 \\
(-0.76 /-0.38)\end{array}$ & 0.14 & 4 \\
\hline 137.1330 & $\mathrm{C}_{10} \mathrm{H}_{16}-\mathrm{H}^{+}$ & $\begin{array}{l}\text { Monoterpenes (and } \\
\text { sesquiterpene fragment) }\end{array}$ & $\begin{array}{r}-1.14 \\
(-2.88 /-0.20)\end{array}$ & 0.27 & 16 \\
\hline
\end{tabular}

with emission only (Kesselmeier and Staudt, 1999), although Noe et al. (2008) observed deposition of monoterpenes to non-emitting species in a laboratory experiment and Himanen et al. (2010) suggested that non-emitting plants may be protected by deposited semivolatiles from neighboring sesquiterpene emitters. As shown in detail in Bamberger et al. (2010), monoterpene deposition occurred during a period of approximately five weeks following a hail storm which triggered large monoterpene emissions from damaged coniferous trees surrounding the study site on the valley slopes. Following the hail storm, ambient monoterpene concentrations were significantly elevated, which represents the presumed cause for the observed deposition to the site which otherwise exhibits close to zero monoterpene fluxes (Bamberger et al., 2010). Harvesting changed the terpenoid flux pattern from deposition to emission (Fig. 2), the cut induced release indicated that mono- and sesquiterpenes are stored inside the vegetation and were released due to the mechanical damage.
VOC fluxes over grassland changed dramatically during harvesting (Figs. 3 and 4). In total we found 17 compounds which were emitted during the grass cutting (Table 3 ) and observed emissions of single-oxygenated $\mathrm{C}_{4}$ and $\mathrm{C}_{5}$ VOCs and $\mathrm{C}_{5} \mathrm{H}_{8} \mathrm{O}_{2}$ as well as mono- and sesquiterpene from grassland for the first time. Laboratory PTR-TOF and adsorbent sample GC-MS measurements confirmed that monoand sesquiterpenes are emitted during drying of clover, one of the forb species growing at the field site (Brilli et al., 2010). Also Hewitt and Street (1992) reported that clover can emit monoterpenes, but not isoprene, and did not screen for other VOC emissions. We propose that the flux of $\mathrm{C}_{4} \mathrm{H}_{6} \mathrm{O}$-compounds is due to direct emission and not a flux of methyl-vinyl-ketone (MVK) and/or methacrolein from isoprene oxidation. This type of direct biogenic emission of MVK has been observed by Folkers et al. (2002) in laboratory measurements of birch, where primary emission of isoprene and it's oxidation to MVK was excluded by isotopic labeling of primary VOC emissions (J. Wildt et al., 

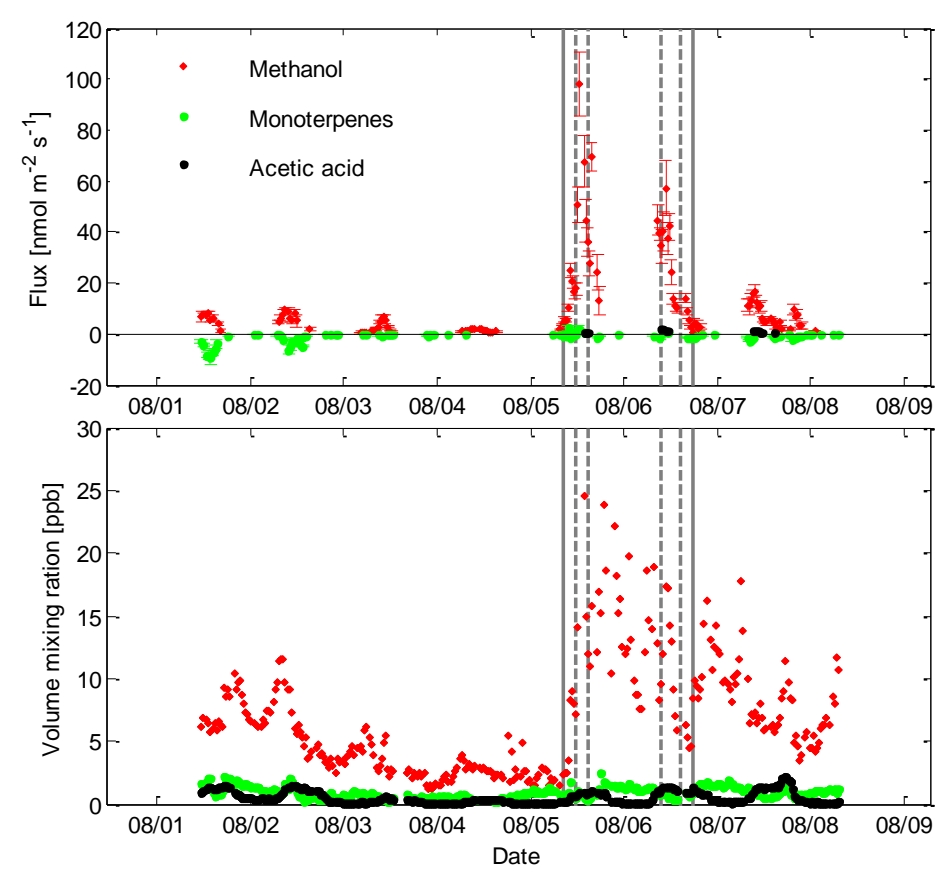

Fig. 3. The temporal behavior of methanol, acetic acid and monoterpenes fluxes (upper panel) $95 \%$ confidence levels are indicated with bars, and volume mixing ratios (lower panel). Cutting of grass on 5 August morning and removal on evening of 6 August is indicated with a solid line and the turnings of the drying grass by dashed lines.

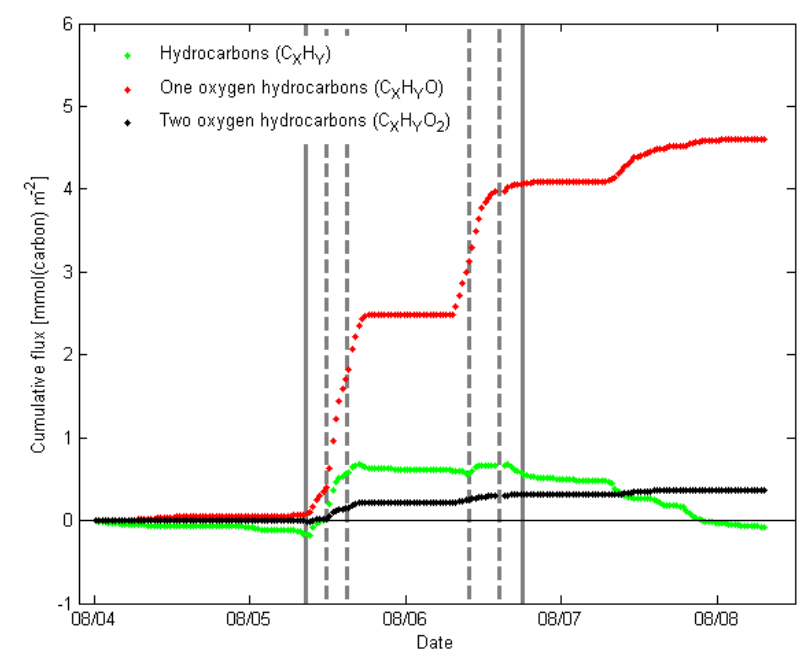

Fig. 4. The cumulative sum of the VOC fluxes of pure hydrocarbons, one oxygen containing VOCs and two oxygen containing VOCs from 1 to 8 August 2009. Linearly interpolated values were used to fill gaps in data that were an hour or less. Cut and remove of grass are indicated with continuous gray line, turnings of drying grass with dashed lines.

personal communication, 2010), and in the field by Jardine et al. (2010) for creosotebush. The $\mathrm{C}_{5}$-compound containing two oxygen atoms was likely furfural, which can be emitted from fruits (Stensmyr et al., 2001), soil bacteria (Leff and
Fierer, 2008) and degeneration of cellulose (Łojewski et al., 2010). Furfural was emitted up to $4.5 \mathrm{nmol} \mathrm{m}^{-2} \mathrm{~s}^{-1}$ during the drying of grass and was not emitted after grass removal indicating that for this site the drying grass was the more important source than soil activity (Tables 3-4). Ethanol emissions during grass drying were substantial, between 2.4 and $8.2 \mathrm{nmol} \mathrm{m}^{-2} \mathrm{~s}^{-1}$, but not observed before or after harvesting. Ethanol emissions due to stress and aerobic metabolism (Davies, 1980) likely also occur outside the harvesting period; due to poor sensitivity for ethanol we could not observe the ethanol emissions before harvesting. All emissions declined rapidly during the drying of cut grass. Out of the 17 species emitted from the freshly cut grass only 8 were emitted after the dried grass had been removed (Table 4). In addition the terpenoid fluxes had changed back to deposition.

Methanol dominated the VOC emissions at all times and emission of methanol from vegetation in general (e.g. Ninemets et al., 2004; Fall et al., 1999) and from grassland is well known (e.g. Brunner et al., 2007; Custer and Schade, 2007; Bamberger et al., 2010). The major biogenic source of methanol is the demethylation of the pectin matrix during the decay or expansion of plant cell walls (Galbally and Kirstine, 2002; Fall, 2003) and methanol emissions have been shown to correlate with plant growth rates (Hüve et al., 2007). Other major driving factors for methanol emissions from leaves appear to be temperature and stomatal conductance (Harley et al., 2007). The latter can be explained by the high solubility of methanol (Niinemets et al., 2004). The magnitude 


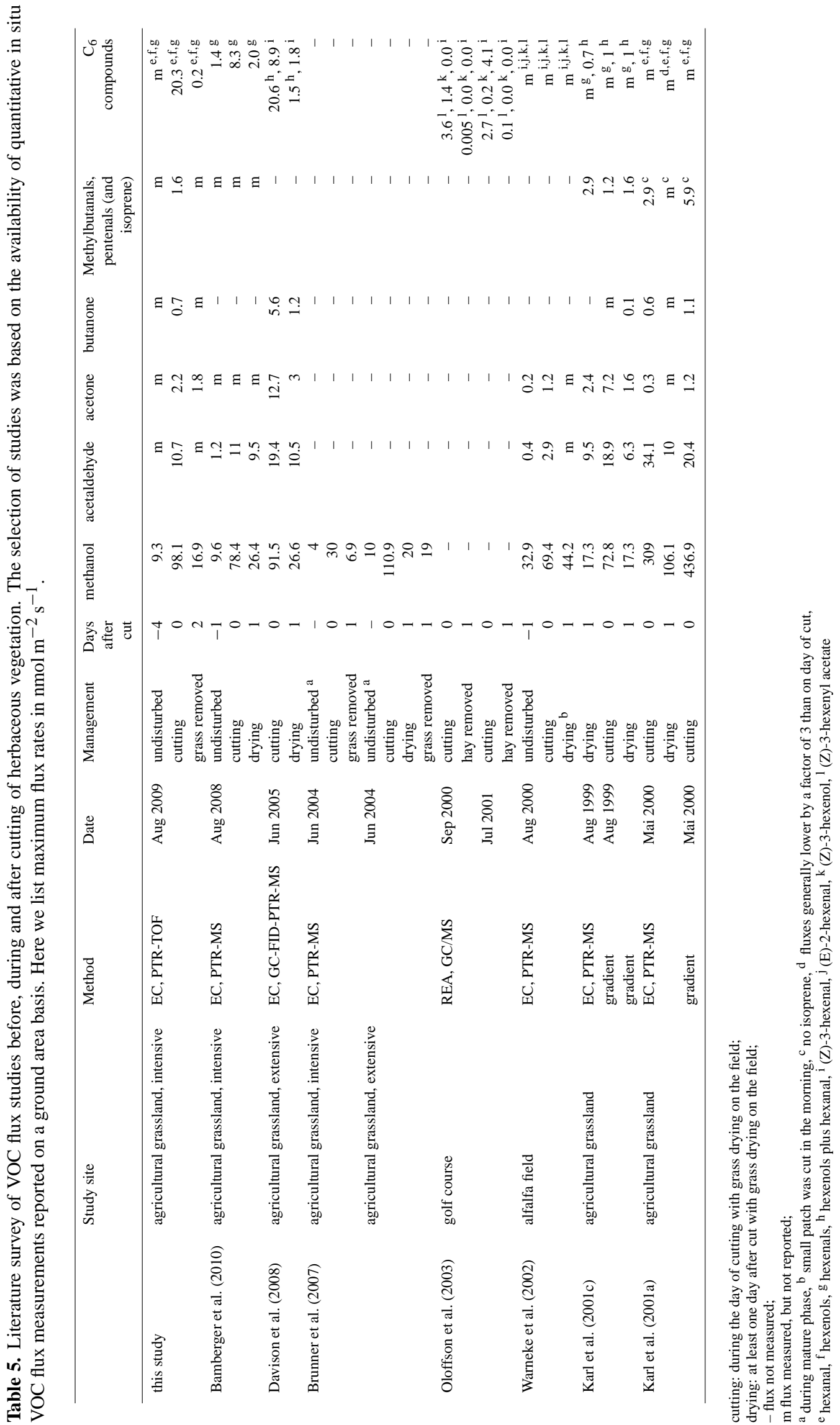



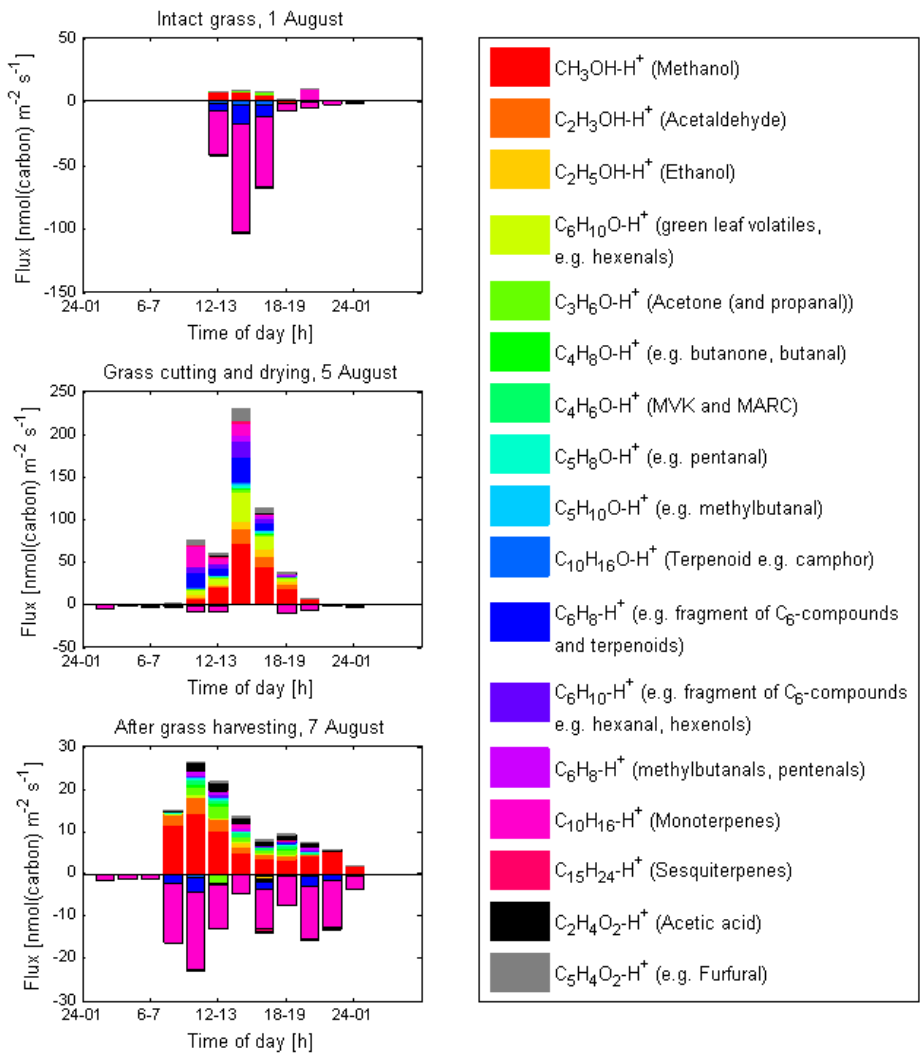

Fig. 5. The diurnal pattern of VOC carbon fluxes from intact grass (1 Aug), cut drying grass (5 Aug) and after grass harvesting (7 Aug) in two hour means of class-A fluxes.

of methanol emissions before cutting agreed extremely well (Table 5) with the results of Bamberger et al. (2010) obtained with a PTRMS for the same site during the previous vegetation period. Observed methanol emissions before cutting were somewhat higher than those reported by Brunner et al. (2007) for an intensively and extensively managed grassland during maturation. Higher methanol emissions were reported by Warneke et al. (2002) for an alfalfa field (Table 5). These differences may be reflective of differences in environmental conditions (e.g. temperature), as well as differences in plant species composition. Highest methanol emissions were consistently observed on the day of cutting and during drying of plants and the peak emissions were typically in the $70-110 \mathrm{nmol} \mathrm{m}^{-2} \mathrm{~s}^{1}$ range (Table 5). Smallest cutting induced emissions were less than one third of these values (Brunner et al., 2010), while on the other hand the largest emissions (Karl et al., 2001a) were over $400 \mathrm{nmol} \mathrm{m}^{-2} \mathrm{~s}^{-1}$. During cutting and drying the VOCs stored inside plants in the gas or liquid phase (Niinemets et al., 2004) escape to the atmosphere through the severed plant cells. The similarity in peak methanol fluxes is striking given the abovementioned likely differences in environmental conditions and plant species composition between studies. In addition, Brilli et al. (2010) have shown that the magnitude of VOC emis- sion after wounding scales with the severed plant area and studies may thus be expected to differ depending on the vertical plant area distribution with respect to the cutting height. Emissions were usually at least 50\% lower during periods when the cut vegetation was left to dry at the field (possibly turned periodically by agricultural machinery; Table 5). This is thought to reflect the depletion of VOC pools within the severed plant material. Finally, after the cut plant material was removed methanol emissions further declined (Table 5) and approached typical growing season background values within several days (Bamberger et al., 2010).

In addition to methanol, the release of $\mathrm{C}_{6}$ leaf wound compounds, acetone and acetaldehyde from cut grass has been observed in several studies (Karl et al., 2001a,c; Warneke et al., 2002; Oloffson et al., 2003; Davison et al., 2008; Bamberger et al., 2010) and counted for the majority of the emitted VOCs. Similar to methanol, emissions of these compounds were highest during the cutting event (acetaldehyde: $3-35 \mathrm{nmol} \mathrm{m}^{-2} \mathrm{~s}^{-1}$; acetone: $1-13 \mathrm{nmol} \mathrm{m}^{-2} \mathrm{~s}^{-1}$ ) as compared to the periods thereafter. Due to differences between studies in how the $\mathrm{C}_{6}$ leaf wound compounds are reported, it is difficult to compare their flux magnitudes (Table 5). 


\subsection{Reactive VOC carbon budget}

We calculated time integrated carbon fluxes (Fig. 4) for three groups: (1) pure hydrocarbons and (2) one and (3) two oxygen containing VOCs. Methanol emissions are an order of magnitude higher than of any other VOC. On a carbon basis it accounts for half of the oxygen containing VOC emissions and less than a third of the total VOC flux (Fig. 5). Longer chained VOCs, especially $\mathrm{C}_{10}-\mathrm{C}_{15}$ terpenoids, account for a significant fraction of the carbon emissions during grass cutting. We also observed deposition fluxes of monoterpenes and sesquiterpenes before and after the harvesting period (Tables 2-4). These deposition fluxes result in a decrease of the cumulative VOC flux shown in Fig. 4 after the grass was removed. Regionally these VOC emissions could play a role for local air quality during periods of intense harvesting activities, especially in areas with some anthropogenic influence where $\mathrm{NO}_{\mathrm{x}}$ is not limiting ozone formation. Future plans to drastically increase the production of biomass as feedstock for the bioenergy and bioproducts industry could increase the atmospheric input of these reactive VOCs.

\section{Summary and conclusion}

We used PTR-TOF to measure VOC eddy covariance fluxes over grassland with a flux detection limit on the order of $0.1 \mathrm{nmol} \mathrm{m}^{-2} \mathrm{~s}^{-1}$. PTR-TOF allowed scanning a wide range of VOCs. A total VOC emission flux up to $200 \mathrm{nmolC} \mathrm{m} \mathrm{m}^{-2} \mathrm{~s}^{-1}$ was measured during harvesting activities. These flux measurements also indicated significant deposition of mono- and sesquiterpenes to intact grassland. The deposition as well as release of unexpected VOCs, including MVK, furfural, mono- and sesquiterpenes, from the drying grass demonstrated the usefulness of expanding VOC flux measurements to a wide range of compounds whose exchange patterns have previously been poorly characterized. Harvesting practices could become an important source of reactive VOC if biofuel crops are grown on large scales and should be considered in emission inventories used for air quality modeling.

Acknowledgements. This study was financially supported by the Austrian National Science Fund (P19849), and the Tyrolean Science Fund (Uni-404/486). Family Hofer (Neustift, Austria) is thanked for granting us access to the study site. Additional support was obtained by the Translational-Research-Programm (L518-N20) of the Austrian National Science Fund and the Industry-Academia Partnerships and Pathways (IAPP; 218065) funded by the European Commission.

Edited by: R. Holzinger

\section{References}

Bamberger, I., Hörtnagl, L., Schnitzhofer, R., Graus, M., Ruuskanen, T. M., Müller, M., Wohlfahrt, G., and Hansel, A.: BVOC fluxes above mountain grassland, Biogeosciences, 7, 1413-1424, 2010 , http://www.biogeosciences.net/7/1413/2010/.

Bamberger, I., Hörtnagl, L., Ruuskanen, T. M., Schnitzhofer, R., Müller, M., Graus, M., Karl, T., Wohlfahrt, G., and Hansel, A.: Deposition fluxes of terpenes over grassland, J. Geophys. Res., in review, 2010.

Brilli, F., Ruuskanen, T. M., Schnitzhofer, R., Müller, M., Breitenlechner, M., Bittner, V., Wohlfahrt, G., Loreto, F., and Hansel, A.: Ultrafast detection of biogenic volatile organic compounds by Proton Transfer Reaction "Time-of-Flight" Mass Spectrometry (PTR-TOF) after leaf wounding and darkening, submitted, PLoS ONE, 2010.

Brunner, A., Ammann, C., Neftel, A., and Spirig, C.: Methanol exchange between grassland and the atmosphere, Biogeosciences, 4, 395-410, 2007, http://www.biogeosciences.net/4/395/2007/.

Chapin, F. S. III, Woodwell, G. M., Randerson, J. T., Rastetter, E. B., Lovett, G. M., Baldocchi, D. D., Clark, D. A., Harmon, M. E., Schimel, D. S., Valentini, R., Wirth, C., Aber, J. D., Cole, J. J., Goulden, M. L., Harden, J. W., Heimann, M., Howarth, R. W., Matson, P. A., McGuire, A. D., Melillo, J. M., Mooney, H. A., Neff, J. C., Houghton, R. A., Pace, M. L., Ryan, M. G., Running, S. W., Sala, O. E., Schlesinger, W. H., and Schulze, E.D.: Reconciling carboncycle concepts, terminology and methods, Ecosystems, 9, 1041-1050, 2006.

Claeys, M., Graham, B., Vas, G., Wang, W., Vermeylen, R., Pashynska, V., Cafmeyer, J., Guyon, P., Andrea, M.O., Artaxo, P., and Maenhaut, W.: Formation of Secondary Organic Aerosols Through Photooxidation of Isoprene, Science, 303, 1173-1176, doi:10.1126/science.1092805, 2004.

Custer, T. and Schade G.; Methanol and acetaldehyde fluxes over ryegrass, Tellus B, 59, 673-684, 2007.

Davies, D. D.: Anaerobic metabolism and the production of organic acid, in: The Biochemistry of Plants, 2, Academic Press, New York, USA, 581-611, 1980.

Davison, B., Brunner, A., Ammann, C., Spirig, C., Jocher, M., and Neftel, A.: Cut-induced VOC emissions from agricultural grasslands, Plant Biol., 10(1), 76-85, 2008.

Di Carlo, P., Brune, W. H., Martinez, M., Harder, H., Lesher, R., Ren, X., Thornberry, T., Carroll, M. A., Young, V., Shepson, P. B., Riemer, D., Apel, E., and Campbell, C.: Missing OH Reactivity in a Forest: Evidence for Unknown Reactive Biogenic VOCs, Science, 304, 722-725, doi:10.1126/science.1094392, 2004.

Fall, R.: Abundant oxygenates in the atmosphere: A biochemical perspective, Chem. Rev., 103, 4941-4951, 2003.

Fall, R., Karl, T., Hansel, A., Jordan, A., and Lindinger, W.: Volatile organic compounds emitted after leaf wounding: On-line analysis by proton-transfer-reaction mass spectrometry, J. Geophys. Res., 104(D13), 15,963-15,974, 1999.

Folkers, A., Koppmann, R., and Wildt, J.: Direct Emission of Methyvinylketone from Birch, American Geophysical Union, Fall Meeting 2002, abstract A61B-0070, 2002.

Galbally, I. E. and Kirstine, W.: The production of methanol by flowering plants and the global cycle of methanol, J. Atmos. Chem., 43, 195-222, 2002. 
Goldstein, A. H. and Galbally, I. E.: Known and unexplored organic constituents in the earth's atmosphere, Environ. Sci. Technol., 41, 1514-1521, 2007.

Graus, M., Müller, M., and Hansel, A.: High resolution PTR-TOF: Quantification and formula confirmation of VOC in real time, J. Am. Soc. Mass Spectr., 21, 1037-1044, 2010.

Hallquist, M., Wenger, J. C., Baltensperger, U., Rudich, Y., Simpson, D., Claeys, M., Dommen, J., Donahue, N. M., George, C., Goldstein, A. H., Hamilton, J. F., Herrmann, H., Hoffmann, T., Iinuma, Y., Jang, M., Jenkin, M. E., Jimenez, J. L., Kiendler-Scharr, A., Maenhaut, W., McFiggans, G., Mentel, Th. F., Monod, A., Prévôt, A. S. H., Seinfeld, J. H., Surratt, J. D., Szmigielski, R., and Wildt, J.: The formation, properties and impact of secondary organic aerosol: current and emerging issues, Atmos. Chem. Phys., 9, 5155-5236, doi:10.5194/acp-95155-2009, 2009.

Hammerle, A., Haslwanter, A., Tappeiner, U., Cernusca, A., and Wohlfahrt, G.: Leaf area controls on energy partitioning of a temperate mountain grassland, Biogeosciences, 5, 421-431, 2008, http://www.biogeosciences.net/5/421/2008/.

Harley, P., Greenberg, J., Niinemets, Ü., and Guenther, A.: Environmental controls over methanol emission from leaves, Biogeosciences, 4, 1083-1099, 2007,

http://www.biogeosciences.net/4/1083/2007/.

Hewitt, C. N. and Street R. A.: A qualitative assessment of the emission of non-methane hydrocarbon compounds from the biosphere to the atmosphere in the UK: present knowledge and uncertainties, Atmos. Environ., 26A, 3069-3077, 1992.

Himanen, S. J., Blande, J. D., Klemola, T., Pulkkinen, J., Heijari, J., and Holopainen J. K.: Birch (Betula spp.) leaves adsorb and rerelease volatiles specific to neighbouring plants - a mechanism for associational herbivore resistance?, New Phytol., 186, 722732, doi:10.1111/j.1469-8137.2010.03220.x., 2010.

Hüve, K., Christ, M. M., Kleist, E., Uerlings, R., Niinemets, Ü., Walter, A., and Wildt, J.: Simultaneous growth and emission measurement demonstrate an interactive control of methanol release by leaf expansion and stomata, J. Exp. Bot., 58, 1783-1793, 2007.

IPCC: Climate Change 2007: The Physical Science Basis, Contribution of Working Group I to the Fourth Assessment Report of the Intergovernmental Panel on Climate Change, edited by: Solomon, S., Qin, D., Manning, M., Chen, Z., Marquis, M., Averyt, K. B., Tignor, M., and Miller, H. L., Cambridge University Press, Cambridge, United Kingdom and New York, NY, USA, 996 pp., 2007.

Jardine, K., Abrell, L., Kurc, S. A., Huxman, T., Ortega, J., and Guenther, A.: Volatile organic compound emissions from Larrea tridentata (creosotebush), Atmos. Chem. Phys., 10, 1219112206, doi:10.5194/acp-10-12191-2010, 2010.

Jordan, A., Haidacher, S., Hanel, G., Hartungen, E., Märk, L., Seehauser, H., Schottkowsky, R., Sulzer, P., and Märk, T. D.: A high resolution and high sensitivity proton-transfer-reaction time-of-flight mass spectrometer (PTR-TOF-MS), Int. J. Mass Spectrom., 286, 122-128, 2009.

Kanakidou, M., Seinfeld, J. H., Pandis, S. N., Barnes, I., Dentener, F. J., Facchini, M. C., van Dingenen, R., Ervens, B., Nenes, A., Nielsen, C. J., Swietlicki, E., Putaud, J. P., Balkanski, Y., Fuzzi, S., Horth, J., Moortgat, G. K., Winterhalter, R., Myhre, C. E. L., Tsigaridis, K., Vignati, E., Stephanou, E. G., and Wilson, J.:
Organic aerosol and global climate modelling: a review, Atmos. Chem. Phys. Discuss., 4, 5855-6024, doi:10.5194/acpd-4-58552004, 2004.

Karl, T., Guenther, A., Lindinger, C., Jordan, A., Fall, R., and Lindinger, W.: Eddy covariance measurements of oxygenated volatile organic compound fluxes from crop harvesting using a redesigned proton-transfer-reaction mass spectrometer, J. Geophys. Res., 106(D20), 24157-24167, doi:10.1029/2000jd000112, 2001a.

Karl, T., Fall, R., Jordan, A. and Lindinger, W.: On-line analysis of reactive VOCs from urban lawn mowing, Environ. Sci. Technol., 35, 2926-2931, 2001b.

Karl, T., Guenther, A., Jordan, A., Fall, R., and Lindinger, W.: Eddy covariance measurement of biogenic oxygenated VOC emissions from hay harvesting, Atmos. Environ., 35, 491-495, 2001c.

Karl, T. G., Spirig, C., Rinne, J., Stroud, C., Prevost, P., Greenberg, J., Fall, R., and Guenther, A.: Virtual disjunct eddy covariance measurements of organic compound fluxes from a subalpine forest using proton transfer reaction mass spectrometry, Atmos. Chem. Phys., 2, 279-291, doi:10.5194/acp-2-279-2002, 2002.

Kesselmeier, J. and Staudt M.: Biogenic volatile organic compounds (VOC): An overview on emission, physiology and ecology, J. Atmos. Chem., 33, 23-88, 1999.

Kiendler-Scharr, A., Wildt, J., Dal Maso, M., Hohaus, T., Kleist, E., Mentel, T. F., Tillmann, R., Uerlings, R., Schurr, U., and Wahner, A.: New particle formation in forests inhibited by isoprene emissions, Nature, 461, 381-384, doi:10.1038/nature08292, 2009.

Laaksonen, A., Kulmala, M., O’Dowd, C. D., Joutsensaari, J., Vaattovaara, P., Mikkonen, S., Lehtinen, K. E. J., Sogacheva, L., Dal Maso, M., Aalto, P., Petäjä, T., Sogachev, A., Yoon, Y. J., Lihavainen, H., Nilsson, D., Facchini, M. C., Cavalli, F., Fuzzi, S., Hoffmann, T., Arnold, F., Hanke, M., Sellegri, K., Umann, B., Junkermann, W., Coe, H., Allan, J. D., Alfarra, M. R., Worsnop, D. R., Riekkola, M. -L., Hyötyläinen, T., and Viisanen, Y.: The role of VOC oxidation products in continental new particle formation, Atmos. Chem. Phys., 8, 2657-2665, doi:10.5194/acp-82657-2008, 2008.

Leff, J. W. and Fierer, N.: Volatile organic compound (VOC) emissions from soil and litter samples, Soil Biol. Biochem., 40, 16291636, 2008.

Lenschow, D. H. and Kristensen, L.: Uncorrelated noise in turbulence measurements, J. Atmos. Ocean. Tech., 2, 68-81, 1985.

Łojewski, T., Sawoszczuk, T., Łagan, J. M., Zieba, K., Baranski, A., and Łojewska, J.: Furfural as a marker of cellulose degradation. A quantitative approach, Appl. Phys. A-Mater., published online, doi:10.1007/s00339-010-5663-7, 2010.

Metzger, A., Verheggen, B., Dommen, J., Duplissy, J., Prevot, A. S. H., Weingartner, E., Riipinen, I. Kulmala, M., Spracklen, D. V., Carslaw, K. S., and Balternsperger, U.: Evidence for the role of organics in aerosol particle formation under atmospheric conditions, P. Natl. Acad. Sci. USA, 107(15), 66466651, doi:10.1073/pnas.0911330107, 2010.

Müller, M., Graus, M., Ruuskanen, T. M., Schnitzhofer, R., Bamberger, I., Kaser, L., Titzmann, T., Hörtnagl, L., Wohlfahrt, G., Karl, T., and Hansel, A.: First eddy covariance flux measurements by PTR-TOF, Atmos. Meas. Tech., 3, 387-395, doi:10.5194/amt-3-387-2010, 2010.

Niinemets, Ü., Loreto, F., and Reichstein, M.: Physiological and physicochemical controls on foliar volatile organic compound 
emissions, Trends Plant Sci., 9, 180-186, 2004.

Niinemets, Ü., Arneth, A., Kuhn, U., Monson, R. K., Peñuelas, J., and Staudt, M.: The emission factor of volatile isoprenoids: stress, acclimation, and developmental responses, Biogeosciences, 7, 2203-2223, 2010.

Olofsson, M., Ek-Olausson, B., Ljungström, E., and Langer, S.: Flux of organic compounds from grass measured by relaxed eddy accumulation technique, J. Environ. Monitoring, 5, 963-970, 2003.

Noe, S. M., Copolovici, L., Niinemets, Ü., and Vaino, E.: Foliar limonene uptake scales positively with leaf lipid content: "nonemitting" species absorb and release monoterpenes, Plant Biol., 10, 129-137, doi:10.1055/s-2007-965239, 2008.

Rinne, J., Taipale, R., Markkanen, T., Ruuskanen, T. M., Hellén, H., Kajos, M. K., Vesala, T., and Kulmala, M.: Hydrocarbon fluxes above a Scots pine forest canopy: measurements and modeling, Atmos. Chem. Phys., 7, 3361-3372, doi:10.5194/acp-73361-2007, 2007.

Sinha, V., Williams, J., Lelieveld, J., Ruuskanen, T. M., Kajos, M. K., Patokoski, J., Hellen, H., Hakola, H., Boy, M., Rinne, J., Kulmala, M.: OH Reactivity Measurements within a Boreal forest: Evidence for Unknown Reactive Emissions, 44, 6614-6620, Env. Sci. Tech., 2010.

Spirig, C., Neftel, A., Ammann, C., Dommen, J., Grabmer, W., Thielmann, A., Schaub, A., Beauchamp, J., Wisthaler, A., and Hansel, A.: Eddy covariance flux measurements of biogenic VOCs during ECHO 2003 using proton transfer reaction mass spectrometry, Atmos. Chem. Phys., 5, 465-481, doi:10.5194/acp-5-465-2005, 2005.

Stensmyr, M. C., Larsson, M. C., Bice, S. and Hansson B. S.: Detection of fruit- and flower-emitted volatiles by olfactory receptor neurons in the polyphagous fruit chafer Pachnoda marginata (Coleoptera: Cetoniinae), J. Comp. Physiol. A, 187, 509-519, doi:10.1007/s003590100222, 2001.
Tunved, P., Hansson, H.-C., Kerminen, V.-M., Ström, J., Dal Maso, M., Lihavainen, H., Viisanen, Y., Aalto, P.P., Komppula, M., and Kulmala, M.: High Natural Aerosol Loading over Boreal Forests, Science, 312, 261-263. doi:10.1126/science.1123052, 2006.

Warneke, C., Luxembourg, S. L., Gouw, J. A., Rinne, H. J. I., Guenther A. B., and Fall, R.: Disjunct eddy covariance measurements of oxygenated volatile organic compounds fluxes from an alfalfa field before and after cutting, J. Geophys. Res., 107(D8), 4067, doi:0.1029/2001JD000594, 2002.

Webb, E. K., Pearman, G. I., and Leuring, R.: Correction of flux measurements for density effects due to heat and water vapor transfer, Quart. J. R. Meteorol. Soc., 106, 85-106, 1980.

Wienhold, F. G., Frahm, H., and Harris, G. W.: Measurements of $\mathrm{N}_{2} \mathrm{O}$ fluxes from fertilized grassland using a fast response tunable diode laser spectrometer, J. Geophys. Res., 99(D8), 1655716567, 1994.

Wilczak, J. M., Oncley, S. P. and Stage, S. A.: Sonic anemometer tilt correction algorithms, Bound.-Lay. Meteorol., 99, 127-150, 2001.

Wohlfahrt, G., Anfang, C., Bahn, M., Haslwanter, A., Newesely, C., Schmitt, M., Drösler, M., Pfadenhauer, J., and Cernusca, A.: Quantifying nighttime ecosystem respiration of a meadow using eddy covariance, chambers and modeling, Agric. Forest Meteorol., 128, 141-162, 2005.

Wohlfahrt, G., Hammerle, A., Haslwanter, A., Bahn, M., Tappeiner, U., and Cernusca, A.: Seasonal and inter-annual variability of the net ecosystem $\mathrm{CO}_{2}$ exchange of a temperate mountain grassland: Effects of weather and management, J. Geophys. Res., 113, D08110, doi:10.1029/2007jd009286, 2008.

Wohlfahrt, G., Pilloni, S., Hörtnagl, L., and Hammerle, A.: Estimating carbon dioxide fluxes from temperate mountain grasslands using broad-band vegetation indices, Biogeosciences, 7, 683-694, 2010,

http://www.biogeosciences.net/7/683/2010/. 